\title{
32. On the Splitting of the Side Chain from Tyrosine by the Action of Aldehydes.
}

\author{
By Shiro AKabori and Kō OHNo. \\ Department of Chemistry, Faculty of Science, Osaka University. \\ (Comm. by R. MA.Jima, M.J.A., June, 12, 1950.)
}

Recently, Akabori and Narita ${ }^{1)}$ reported that, when tryptophan was treated with aldehydes in acidic conditions, serine and alanine were produced. This fact shows that tryptophan condenses with aldehydes with its indole group and splits off the alanine side chain. Therefore, it seems worth while to study whether the analogous reaction would take place between tyrosine and aldehydes, for it is well known, that phenols condense readily with aldehydes forming resinous matters, and if aldehydes attack at the paraposition to the hydroxyl group of tyrosine, alanine or serine should by produced as in the case of tryptophan.

On the other hand, K. Ichihara ${ }^{2)}$ and K. Felix and K. Zorn ${ }^{3)}$ reported that alanine was enzymatically formed from tyrosine. According to R. V. Pitt-Rivers ${ }^{4}$, alanine was identified as a byproduct of in vitro formation of thyroxine from 3.5-diiodtyrosine. These studies indicate, that the linkage between phenol group and alanine side chain has a tendency to be splitt off under certain conditions. Present paper shows it too, and further it offers some notice to the analysis of acid hydrolysate of proteins.

The conditions of the present study are similar to the above mentioned report (1). When tyrosine was heated with benzaldehyde in a mixture of acetic acid and hydrochloric acid, a dark red solution was obtained. In the reaction mixture serine, alanine and tyramine were detected by means of paper chromatography, and the both amino acids were isolated as azobenzene-p-sulfonate and p'-hydroxy-azobenzene-p-sulfonate respectively.

By heating tyrosine with glucose, we found almost the same products. To confirm whether this reaction is specific to aromatic amino acids or not, and if alanine or serine would be produced by

1) S. Akabori and K. Narita: Proc. Acad. Japan (in press).

2) K. Ichihara and Y. Taketomo: 21st Meeting of Japanese Biochem. Ass. (1949). K. Ichihara, M. Uchida and Y. Kakihara : 22nd Meeting of Japanese Biochem. Ass. (1950).

3) K. Felix and K. Zorn: Z. physiol. Chem. 258, 16 (1939) ; 268, 257 (1941).

4) R. V. Pitt-Rivers: Biochem. J. 43, 223 (1948). 
transamination from tyrosine to pyruvic acid which might be formed by the decomposition of glucose. We treated leucine with glucose under the same conditions, but, in the reaction mixture, no amino acids other than leucine could be detected.

In general, phenols condense with aldehydes at their orthoand para-positions, and we consider the reaction between tyrosine and benzaldehyde proceeds as follows:

2<smiles>CCCCCCCC(=O)OCC(N)C(=O)O</smiles>

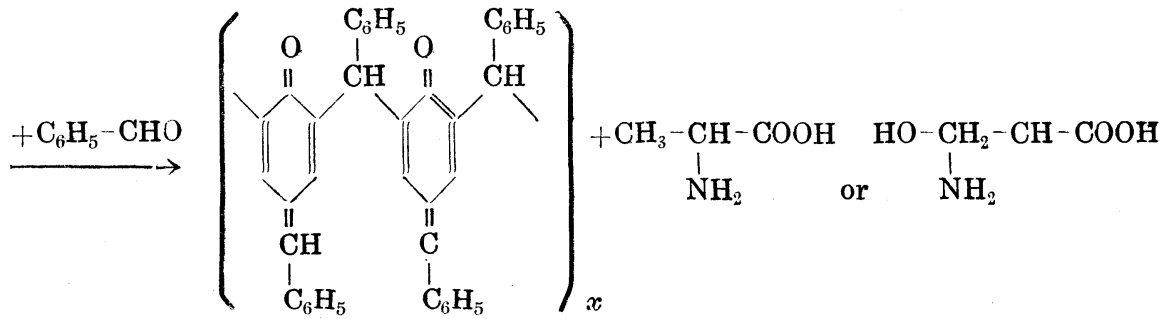

The resinous condensation product actually obtained contains nitrogen, dissolves in acid and alkali, giving reddish brown color, and is, therefore, supposed to be a mixture of I, II and III, showing the splitting of the side chain is incomplete. The reaction between tyrosine and glucose should proceed in the analogous way. But, glucose itself undergoes complicate change in strong acids, the product naturally being quite different from that in the case of benzaldehyde.

\section{Experimental}

(1) Reaction between tyrosine and benzaldehyde. 5gm L-tyrosine was dissolved in $50 \mathrm{ml}$ of the acid mixture consisted of equal volumes of glacial acetic and $20 \%$ hydrochloric acid, various amounts of benzaldehyde were added, and kept at various temperatures or boiled under reflux condenser. Conditions of the reaction and the results are shown in the following table.

(2) Isolation of alanine. $5 \mathrm{gm}$ tyrosine and $9 \mathrm{gm}$ benzaldehyde were dissolved in $50 \mathrm{ml}$ of the acid mixture and heated to boiling for 5 hours. The resulting mixture was concentrated in vacuo to 


\begin{tabular}{|c|c|c|c|c|c|c|}
\hline \multirow{2}{*}{ No. of exper. } & \multirow{2}{*}{$\begin{array}{c}\text { Mol. ratio } \\
\text { tyrosine : ald. }\end{array}$} & \multirow{2}{*}{$\begin{array}{c}\text { Reaction } \\
\text { temp. }\end{array}$} & \multirow{2}{*}{$\begin{array}{l}\text { Time of } \\
\text { reaction }\end{array}$} & \multicolumn{3}{|c|}{ Reaction products } \\
\hline & & & & Alanine & Serine & Tyramine \\
\hline 1 & $-\cdots$ & boil. & $7 \mathrm{hrs}$. & - & - & - \\
\hline 2 & $2: 1$ & ,, & 6 ,, & \pm & \pm & - \\
\hline 3 & $1: 1$ & $20^{\circ}$ & 5 days. & - & - & - \\
\hline 4 & $1: 1$ & $60^{\circ}$ & $10 \mathrm{hrs}$. & - & - & - \\
\hline 5 & $1: 1$ & $100^{\circ}$ & 7, & + & + & + \\
\hline 6 & $1: 2$ & boil. & 5, & ++ & ++ & ++ \\
\hline 7 & $1: 3$ & boil. & 7, & +++ & ++ & ++ \\
\hline
\end{tabular}

a syrup, diluted with water and again concentrated in vacuo to remove the acid solvent and benzaldehyde. $3.9 \mathrm{gm}$ benzaldehyde was recovered from the distillate. The syrup was dissolved in 30 $\mathrm{ml}$ of distilled water and decolorized by boiling with about $5 \mathrm{gm}$ active carbon, which became a paste. This was filtered off and the solution treated again with active carbon. The clear solution was concentrated to a few $\mathrm{ml}$, ca. $0.5 \mathrm{~g}$ azobenzene-p-sulfonic acid was added to it and brought to the complete dissolution by boiling. On cooling, an yellow precipitate came out. After being kept in ice box over night, the precipitate was collected and recrystallized twice from distilled water.

Yellow fine crystals thus obtained weighed $43 \mathrm{mgm}$. Its nitrogen content was determined by micro-Dumas.

$\begin{array}{lll}\text { Found } & \mathrm{N} & 11.93 \% \\ \text { Calc. for } \mathrm{C}_{15} \mathrm{H}_{19} \mathrm{O}_{5} \mathrm{~N}_{3} \mathrm{~S} & \mathrm{~N} & 11.93 \%\end{array}$

This salt gave only alanine and azobenzene-p-sulfonic acid spots on the paper chromatogram.

(3) Isolation of serine. The reaction mixture started from 30 $\mathrm{gm}$ tyrosine and $35 \mathrm{gm}$ benzaldehyde was treated in the same way as above. The filtrate from alanine azobenzene-p-sulfonate was concentrated to $3 \mathrm{ml}$ in vacuo. To this solution a small quantity of p'-hydroxy-azobenzene-p-sulfonic acid was dissolved and kept in ice box for several days. Yellow precipitate thus obtained weighed $2 \mathrm{mg}$. The result of micro-Dumas showed a good accordance with serine p'-hydroxy-azobenzene-p-sulfonate.

$\begin{array}{lll}\text { Found } & \mathrm{N} & 10.70 \% \\ \text { Calc. for } \mathrm{C}_{15} \mathrm{H}_{17} \mathrm{O}_{7} \mathrm{~N}_{8} \mathrm{~S} & \mathrm{~N} & 10.96 \%\end{array}$

In this salt only serine but no other amino acids were detected on the paper chromatogram. 